\title{
PARK7 Gene
}

National Cancer Institute

\section{Source}

National Cancer Institute. PARK7 Gene. NCI Thesaurus. Code C104714.

This gene plays a role in the modulation of apoptotic signaling. 